\title{
Correction to: Half-graben inversion tectonics revealed by gravity modeling in the Mikawa Bay region, Central Japan
}

Ayumu Miyakawa*, Tomoya Abe, Tatsuya Sumita and Makoto Otsubo

\section{Correction to: Prog Earth Planet Sci 7, 63 (2020) \\ https://doi.org/10.1186/s40645-020-00376-6}

After publication of this article (Miyakawa et al., 2020), it is requested that the additional file 1 and additional file 4 cannot be opened.

The complete additional file 1 and additional file 4 are included in the Supplementary information section of this correction. The original paper has been updated.

\section{Supplementary Information}

The online version contains supplementary material available at https://doi. org/10.1186/s40645-020-00389-1.

Additional file 1.

Additional file 4.

Published online: 17 November 2020

\section{Reference}

Miyakawa et al (2020) Half-graben inversion tectonics revealed by gravity

modeling in the Mikawa Bay Region, Central Japan. Prog Earth Planet Sci 7:

$63 \mathrm{https}: / / \mathrm{doi} .0 \mathrm{rg} / 10.1186 / \mathrm{s} 40645-020-00376-6$

The original article can be found online at https://doi.org/10.1186/s40645020-00376-6.

*Correspondence: miyakawa-a@aist.go.jp

Geological Survey of Japan, AIST, AIST Tsukuba Central 7, 1-1-1 Higashi,

Tsukuba, Ibaraki 305-8567, Japan

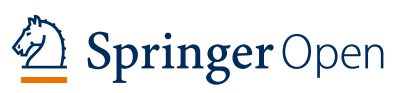

(c) The Author(s). 2020 Open Access This article is licensed under a Creative Commons Attribution 4.0 International License, which permits use, sharing, adaptation, distribution and reproduction in any medium or format, as long as you give appropriate credit to the original author(s) and the source, provide a link to the Creative Commons licence, and indicate if changes were made. The images or other third party material in this article are included in the article's Creative Commons licence, unless indicated otherwise in a credit line to the material. If material is not included in the article's Creative Commons licence and your intended use is not permitted by statutory regulation or exceeds the permitted use, you will need to obtain permission directly from the copyright holder. To view a copy of this licence, visit http://creativecommons.org/licenses/by/4.0/. 